\title{
Analisis dampak pelabuhan ikan - ppn prigi terhadap peningkatan pendapatan wilayah Kecamatan Watulimo, Kabupaten Trenggalek dengan metode input- output analisis
}

\author{
Nurhadi $^{1^{*}}$, Sumarsono ${ }^{1}$ \\ ${ }^{1}$ Balai Teknologi Hidrodinamika, BPPT, Surabaya \\ *Corresponding author email: nrhadi@gmail.com
}

Submitted: 30 Agustus 2017 / Revised: 11 Desember 2017 / Accepted: 22 Desember 2017

http://dx.doi.org/10.21107/jk.v10i2.3132

\begin{abstract}
ABSTRAK
Pembangunan pelabuhan perikanan mempunyai peranan penting dalam upaya untuk membangun masyarakat perikanan di sekitar pelabuhan. Dengan adanya pelabuhan perikanan di suatu daerah diharapkan mampu mewujudkan daerah tersebut berpotensi unggul dalam sektor perikanan dan industri terkait, sehingga mampu meningkatkan perekonomian atau pendapatan daerah kawasan tersebut. Pelabuhan Perikanan Prigi adalah salah satu contoh pelabuhan yang telah dibangun dan memiliki berbagai pendukung industri dan fasilitas bagi sektor perikanan, serta hasil produksi yang cukup bersaing. Dengan analisa Input-Output (IO) dilihat seberapa besar produk-produk perikanan di pelabuhan Prigi mempengaruhi perkembangan perekonomian atau pendapatan wilayah tersebut.

Dari hasil analisa terlihat bahwa keunggulan sektor perikanan yang kurang memiliki keterkaitan kebelakang, sehingga diperlukan upaya peningkatan pembinaan dan investasi bidang tersebut.
\end{abstract}

Kata kunci :Pelabuhan perikanan, produksi, analisa input-output,keterkaitan kebelakang

\begin{abstract}
The development of fishery ports has an important role in the effort to develop fisheries communities around the harbor. With the fishery ports in an area is expected to realize that area has the potential in fishery sector and related industries, so can gain the economy or income of the region.

Prigi Fishery Port is one example of a port that is built and has a variety of industrial support and facilities for the fishery sector, as well as production results are quite competitive. With the Input-Output (IO) analysis, it will seen how large the fishery products in Prigi port affect to the economic development or income of the region. From the results seen the existence of fisheries sector have less backward linkage, so it is necessary efforts to increase coaching and investment in these fields.
\end{abstract}

Keywords: Fishery port, production, input-output analysis, backward linkage

\section{PENDAHULUAN}

Pelabuhan Perikanan Prigi adalah pelabuhan yang temasuk pelabuhan perikanan pantai. Pelabuhan perikanan ini terletak di Provinsi Jawa Timur, Kabupaten Trenggalek, Kecamatan Watulimo, Kelurahan Prigi. Pelabuhan Perikanan Nusantara (PPN Prigi) terdapat di area Teluk Prigi, dasar perairan di Teluk Prigi merupakan lumpur bercampur pasir sedikit berbatu karang dengan kedalaman sekitar 15-61 m, yang sebagian besar pantainya sudah terbuka dan hanya sebagian kecil saja yang masih terdapat hutan. Teluk Prigi juga mempunyai tiga pantai yang digunakan untuk wisata, yaitu Pantai Damas, Pantai Prigi dan Pantai Karanggongso.

Fasilitas fungsional yang terdapat di PPN Prigi yaitu dua buah Tempat Pelelangan Ikan (TPI) yang terdapat di tiap dermaga, instalasi PDAM, instalasi bahan bakar, instalasi listrik, bengkel, pagar keliling, tempat pengolahan hasil perikanan, pabrik es dan dua buah cold storage. Bangunan TPI merupakan milik PPN Prigi namun dikelola oleh petugas TPI dibawah Dinas Kelautan dan Perikanan Trenggalek. PPN Prigi juga membangun bengkel untuk pelayanan kapal serta pagar keliling untuk keamanan. Tempat 
pengolahan yang telah tersedia di area PPN Prigi adalah bangsal pengolahan yangmerupakan hasil Kelompok Usaha bersama (KUB) dibawah Ditjen Pengolahan dan Pemasaran Hasil Perikanan (Ditjen P2HP). Tempat pemindangan ikan di Bengkorok merupakan milik Dinas Kelautan dan Perikanan Trenggalek, namun belum berfungsi secara maksimal. Kapal yang digunakan di perairan Prigi adalah kapal motor dengan bahan kayu yang memiliki ukuran $<30$ GT. Kapal yang memiliki ukuran $<10$ GT merupakan kapal yang digunakan untuk mengoperasikan pancing ulur, sedangkan kapal dengan ukuran 10 hingga <30 GT kebanyakan digunakan untuk mengoperasikan alat tangkap tonda, gillnet, dan payang. Kapal dengan ukuran 20 hingga $<30$ GT digunakan untuk mengoperasikan purse seine, dimana untuk mengoperasikan satu unit purse seine dibutuhkan 2 kapal (Ermawan dan Rifian Wilyadrin, 2008).

Pelabuhan Prigi sebagaimana pelabuhan perikanan lainnya mempunyai peranan penting yang meliputi 3 (tiga) aspek, yaitu (a) penunjang pembangunan dan pengembangan ekonomi nasional maupun regional, (b) menunjang pembangunan dan pengembangan industri baik hulu maupun hilir, (c) membangun masyarakat (perikanan) di sekitar pelabuhan perikanan sehingga menjadi lebih kreatif dan dinamis.

Pengembangan sektor perikanan perlu diarahkan untuk dapat meningkatkan peran dalam menciptakan keterkaitan yang kuat dengan sektor yang lain baik keterkaitan ke depan maupun ke belakang melalui peningkatan nilai tambah, penyerapan tenaga kerja, dan pendapatan (Adhyaksa Dault, Abdul Kohar M dan Agus Suherman, 2008).

Pengembangan pelabuhan perikanan diharapkan mampu meningkatkan peranannya dalam menciptakan keterkaitan dengan sektor yang lain antara lain melalui peningkatan nilai tambah, penyerapan tenaga kerja, dan peningkatan pendapatan, yang pada akhirnya menumbuhkan kegiatan perekonomian, dalam kasus ini di Prigi, Trenggalek.

Prinsip saling berhubungan dan keterkaitan tersebut meliputi (Dahuri, 2003):

a) Keterkaitan antara industri pengolahan dengan sumberdaya dan pemasarannya, dalam hal penyediaan bahan bakubagi industri pengolahan untuk meningkatkan nilai tambah sektor perikanan.

b) Keterkaitan antara industri pengolahan yaitu industri hulu, industri hilir, dan industri kecil, terutama untuk menyediakan bahan baku bagi industri pengolahan tersebut.

c) Keterkaitan antara industri pengolahan dengan industri pendukung seperti industri mesin, agrokimia, dan pengemasan.

Keterkaitan antara industri pengolahan dengan sektor ekonomi dan sektor-sektor lainnya seperti, sektor perhubungan, sektor jasa, dan perbaikan.

\section{MATERI DAN METODE}

\section{A. Data Penelitian}

Metode penelitian yang digunakan adalah menggunakan data sekunder yang berasal dari Tabel Trenggalek dalam Angka 2014 (BPS Kab. Trenggalek, 2014), data produksi dari website Kementrian Perikanan dan Kelautan, serta datadata yang didapatkan dari internet, namun dari data yang didapatkan belum memadai untuk melaksanakan analisa metode Input Output (I-O) secara sempurna, sehingga masih diperlukan survey data terbaru untuk hasil yang optimal. Data-data yang ada dianalisis dengan menggunakan metode input-output analisis (IO) dengan melihat keterkaitan ke depan dan keterkaitan ke belakang

\section{B. Analisa dengan Tabel Input-Output}

Tabel Input-output merupakan tabel I-O adalah suatu tabel yang menyajikan informasi tentang transaksi barang dan jasa yang terjadi antar sektor produksi di dalam suatu ekonomi dengan bentuk penyajian berupa matriks. Angka-angka di dalam tabel I-O menunjukkan hubungan dagang antar sektor yang berada dalam perekonomian suatu wilayah.

Tujuan umum model I-O ialah untuk menjelaskan besaran aliran antar industry dalam hubungannya dengan tingkat produksi dalam setiap sektor. Satu aspek yang sangat penting dalam perekonomian yaitu hubungan antar industri. Hubungan ini bersifat saling ketergantungan satu dengan yang lain. Hasil produksi satu macam produksi berarti bahan dasar bagi industri lain, atau dengan kata lain, keluaran industri merupakan masukan bagi industri. Oleh karena itu perubahan pada suatu industri akan berpengaruh pada industri yang lainnya. Perubahan input menyebabkan perubahan output, yang berarti perubahan masukan bagi industri lain, dan dengan demikian secara berantai pengaruh ini akan dirasakan oleh industri yang saling berkaitan tadi. Dari hubungan seperti ini jelas terlihat adanya 
pengaruh timbal balik. Hubungan inilah yang disebut sebagai hubungan Input-Output (Soemarno, 2011).

Pengaruh perubahan dalam satu industri pada industri lain bergerak secara berantai. Hubungan ini dapat dikalsifikasikan menjadi tiga macam, yaitu:

(a). Hubungan langsung, adalah pengaruh yang secara langsung dirasakan oleh sektor yang menggunakan input dari output sektor yang bersangkutan. Misalnya, kalau hasilperikanan menaikkan produksinya menjadi dua kali lipat maka permintaan akan es, tempat penyimpanan juga akan naik lebih kurang dua kali lipat. Kenaikan industri perikanan pasti akan berpengaruh terhadap industri lainnya, seperti pengangkutan.

(b). Hubungan tidak langsung, adalah pengaruh terhadap industri yang outputnya tidak digunakan sebagai input bagi keluaran industri yang bersangkutan. Misalnya, pengaruh industri perikanan terhadap industri jasa pengangkutan.

(c). Hubungan Sampingan, adalah pengaruh tidak langsung yang lebih panjang lagi jangkauannya daripada pengaruh langsung tersebut di atas. Misalnya, Peningkatan produksi sektor industri tertentu akan meningkatkan pendapatan nelayan, atau peningkatan jumlah nelayan yang berarti pula peningkatan sejumlah nelayan tersebut. Dengan pepeningkatan pendapatan ini maka permintaan atau kebutuhan beras dapat naik.

Hubungan input-output mempunyai makna bahwa output suatu sektor menjadi input sektor lainnya. Struktur dari model I-O dibahas dengan menggunakan beberapa simbol (Badan Pusat Statistik, 2008) yang dalam pemodelan didefinisikan sbb:

$$
\begin{aligned}
& Z_{i}=\text { jumlah persediaan barang } i \\
& X_{i}=\text { jumlah produksi barang } i \\
& M_{i}=\text { impor barang } i \\
& X_{i j}=\text { banyaknya barang } i \text { yang digunakan } \\
& \text { oleh sektor } j \\
& Y_{i}=\text { permintaan akhir barang } i \\
& W_{i}=\text { jumlah penggunaan antara barang } i \\
& \left(=X_{i j}\right) \\
& U_{j}=\text { jumlah penggunaan sektor } j\left(=X_{i j}\right) \\
& V_{j}=\text { jumlah penggunaan nilai tambah atau } \\
& \text { primary input dalam sektor } j .
\end{aligned}
$$

Persamaan pertama diturunkan dari baris Tabel 1, yang menunjukkan keseimbangan antara penawaran dengan permintaan, atau penawaran sama dengan permintaan, persamaan ini dinyatakan dengan :

$$
\begin{aligned}
& \mathrm{Z}_{\mathrm{i}}=\mathrm{M}_{\mathrm{i}}+\mathrm{X}_{\mathrm{i}}=\Sigma \mathrm{W}_{\mathrm{i}}+\mathrm{Y}_{\mathrm{i}} \\
& (\text { pemasaran })=\text { (permintaan) } \\
& (\mathrm{i}=1,2,3, \ldots . .)
\end{aligned}
$$

\begin{tabular}{|c|c|c|c|c|c|c|c|c|c|c|c|c|c|c|}
\hline & \multicolumn{9}{|c|}{ Sektor penggunaan } & \multirow[t]{3}{*}{ Jml } & \multirow{3}{*}{$\begin{array}{c}\begin{array}{c}\text { Jml } \\
\text { Penggunan }\end{array} \\
\text { Jumlah } \\
\text { Persediaan }\end{array}$} & \multicolumn{2}{|c|}{ Persediaan } \\
\hline & & \multicolumn{4}{|c|}{ Penggunaan antara } & \multirow[t]{2}{*}{ Jmlh } & \multicolumn{4}{|c|}{$\begin{array}{l}\text { Penggunaan } \\
\text { akhir }\end{array}$} & & & $\begin{array}{l}\text { Im- } \\
\text { por }\end{array}$ & Produksi \\
\hline & & \multicolumn{2}{|c|}{$1 \ldots i$} & \multicolumn{2}{|c|}{ j....n } & & 1 & C & \multicolumn{2}{|c|}{$G$} & & & & \\
\hline \multirow[t]{2}{*}{ Sektor } & 1 & $\mathrm{X} 11$ & Xii & $X_{i j}$ & Xin & W1 & 11 & C1 & G1 & $\mathrm{E} 1$ & Y1 & Z1 & M1 & $\mathrm{X} 1$ \\
\hline & $\mathrm{i}$ & Xi1 & Xii & $\mathrm{ij}$ & Xin & Wi & li & $\mathrm{Ci}$ & $\mathrm{Gi}$ & $\mathrm{Ei}$ & Yi & $\mathrm{Zi}$ & $\mathrm{Mi}$ & $\mathrm{Xi}$ \\
\hline \multirow{2}{*}{ Produksi } & j & Xj1 & $\mathrm{Xji}$ & $X_{j j}$ & Xjn & $W_{j}$ & $\mathrm{lj}$ & $\mathrm{Cj}$ & $\mathrm{Gj}$ & $\mathrm{Ej}$ & $Y j$ & $Z \mathrm{j}$ & $\mathrm{Mj}$ & $x j$ \\
\hline & $\mathrm{n}$ & $\mathrm{Xn} 1$ & Xni & ni & Xnn & Wn & In & $\mathrm{Cn}$ & Gn & En & Yn & $\mathrm{Zn}$ & $\mathrm{Mn}$ & $\mathrm{Xn}$ \\
\hline $\begin{array}{c}\text { Jumlah } \\
\text { input }\end{array}$ & & $\mathrm{U} 1$ & $\mathrm{Ui}$ & Uj & Un & II & I & & & & & & & \\
\hline \multicolumn{2}{|c|}{ Nilai tambah } & $\mathrm{V} 1$ & $\mathrm{Vi}$ & $\mathrm{Vj}$ & $\mathrm{Vn}$ & III & $\begin{array}{l}\text { V1 } \\
\text { IV }\end{array}$ & vc & va & ve & & & & \\
\hline \multicolumn{2}{|l|}{ Jml Prod } & $\mathrm{x} 1$ & $\mathrm{xi}$ & $x j$ & $\mathrm{xn}$ & & 1 & $\mathrm{C}$ & $G$ & $E$ & Y & Z & M & $x$ \\
\hline
\end{tabular}

Persamaan ke dua diturunkan dari kolom Tabel 1, menunjukkan keseimbangan antara jumlah produksi dalam setiap sektor dengan harga input yang dipakai dari sektor lain ditambah nilai tambah dalam sektor tersebut, persamaan ini dinyatakan dengan :

$$
\begin{aligned}
& X_{j}=\sum X_{i j}+V_{j}=U_{j}+V_{j} \\
& (j=1,2,3, \ldots \ldots .)
\end{aligned}
$$

Kedua persamaan di atas mencerminkan definisi FD $\left(\mathrm{Y}_{\mathrm{i}}\right)$ dan nilai tambah $\left(\mathrm{V}_{\mathrm{j}}\right)$.

Tabel 1. Struktur table I-O $\left(M_{i}+X_{i}=\right.$ penawaran; $X_{i j}+Y_{i}=$ permintaan $)$ 
Tabel I-O dibagi dalam empat kuadran yaitu :(a) Kuadran I, terdiri atas penggunaan akhir barang dan jasa yang diproduksi dan dibagi menjadi empat macam penggunaan utama, yaitu investasi (I), konsumsi (C), pemerintah (G) dan ekspor (E); (b) Kuadran II merupakan bagian utama dalam perhitungan antar industri. Setiap sel $X_{i j}$ menunjukkan jumlah barang i yang digunakan oleh sektor $\mathrm{j}$, diukur dalam harga yang tetap; (c) Kuadran III terdiri atas penggunana input yang bersifat penting, tetapi tidak diproduksi dalam sistem. Dalam model statis, penggunaan persediaan modal yang ada adalah input pokok atau nilai tambah sebagaimana halnya buruh dan tanah. Jumlah pembayaran untuk input pokok oleh setiap sektor akan menghasilkan harga yang hampir sama dengan nilai tambah di dalam produksi; (d) Kuadran IV terdiri atas input langsung faktor nilai tambah ke penggunaan akhir.

\section{Dasar Perhitungan I-O}

Anggapan dasar yang terpenting ialah:

a) Suatu produk tertentu hanya dilayani oleh satu sektor

b) Tidak ada produksi gabungan (joint product)

c) Jumlah kuantitas setiap masukan yang digunakan dalam produksi oleh setiap sektor ditentukan seluruhnya oleh tingkat keluaran setiap sektor tersebut.

Anggapan ini akan menurunkan suatu persamaan yang menunjukkan kebutuhan setiap industri terhadap setiap barang sebagai suatu fungsi tingkat outputnya.

$$
\begin{array}{ll}
X_{i j}=X_{i j}+a_{i j} X_{j} & (4) \\
X_{i j}=a_{i j} X_{j} j i k a X_{i j}=0 & (5) \\
a_{i j}=\text { koefisien input marjinal; } X_{i j}= \\
\text { konstanta. }
\end{array}
$$

Dari kombinasi persamaan (5) dan (1), yaitu dengan mensubstitusikan nilai $X_{i j}$, kita memperoleh persamaan sbb:

$$
\mathrm{X}_{\mathrm{i}}-\sum \mathrm{a}_{\mathrm{ij}} \mathrm{X}_{\mathrm{j}}=\mathrm{Y}_{\mathrm{i}}-\mathrm{M}_{\mathrm{i}}
$$

Jika perdagangan merupakan faktor penting, seringkali impor dibuat sebagai suatu variabel yang ditentukan (dependent). Sebagai pendekatan pertama dapat dianggap bahwa tingkat impor $\left(\mathrm{M}_{\mathrm{i}}\right)$ merupakan suatu fungsi penawaran barang tersebut (yang diimpor $Z_{i}$ ), dan selanjutnya akan berhubungan dengan tingkat produksi dalam negeri $\left(X_{i}\right)$. Dengan anggapan bahwa semua hubungan ini merupakan suatu fungsi linear, dapat diturunkan suatu persamaan sbb:

$$
\mathrm{M}_{\mathrm{i}}=\overline{\mathrm{M}}_{\mathrm{i}}+\mathrm{m}_{\mathrm{i}} \mathrm{X}_{\mathrm{i}}(7)
$$

FD (Final Demand) merupakan selisih antara jumlah persediaan suatu barang yang tersedia dengan jumlah yang digunakan dalam produksi, termasuk di dalamnya perubahan persediaan. Input pokok didefinisikan sebagai selisih antara nilai produksi dalam suatu sektor dengan jumlah pengeluaran untuk input yang dibeli dari sektor produktif lainnya. Dari definisi ini akan terlihat hubungan antara perhitungan $\mathrm{I}-\mathrm{O}$ dengan penjumlahan atau perhitungan pendapatan.

Dengan menjumlahkan persamaan (1) dari setiap baris dan menganggap impor merupakan pengurangan FD, diperoleh persamaan sbb:

$$
\sum \mathrm{X}_{\mathrm{i}}=\sum \sum \mathrm{X}_{\mathrm{ij}}+\sum \mathrm{Y}_{\mathrm{i}}+\sum \mathrm{M}_{\mathrm{i}}
$$

Persamaan (2) dapat dikembangkan menjadi:

$$
\begin{aligned}
& \sum \mathrm{X}_{\mathrm{j}}=\sum \sum \mathrm{X}_{\mathrm{ij}}+\sum \mathrm{V}_{\mathrm{j}} \\
& \sum \mathrm{X}_{\mathrm{i}}=\sum \mathrm{X}_{\mathrm{j}} \\
& \sum \mathrm{Y}_{\mathrm{i}}-\sum \mathrm{M}_{\mathrm{i}}=\sum \mathrm{V}_{\mathrm{j}}
\end{aligned}
$$

$m_{i}$ yang merupakan koefisien impor sangat erat hubungannya dengan hasrat marjinal impor sutau barang tertentu.

$$
\begin{aligned}
& \mathrm{X}_{\mathrm{i}}-\sum \mathrm{a}_{\mathrm{ij}} \overline{\mathrm{X}}_{\mathrm{j}}=\mathrm{Y}_{\mathrm{i}}-\mathrm{M}_{\mathrm{i}}(\mathrm{i}=1,2,3 \ldots, \mathrm{n}) \\
& \bar{Y}_{\mathrm{i}}=\sum \overline{\mathrm{X}}_{\mathrm{ij}}+\mathrm{Y}_{\mathrm{i}}
\end{aligned}
$$

Dari kombinasi persamaan (7) dan (8) dapat diperoleh suatu persamaan sbb:

$$
\left(1+\mathrm{m}_{\mathrm{i}}\right) \mathrm{X}_{\mathrm{i}}-\sum \mathrm{a}_{\mathrm{ij}} \overline{\mathrm{X}}_{\mathrm{j}}=\mathrm{Y}_{\mathrm{i}}
$$

$$
\bar{Y}_{i}=\bar{Y}_{i}+\sum \bar{X}_{i j}-M_{i}(i=1,2,3 \ldots . n)
$$

Variabel $\bar{Y}_{i}$ merupakan jumlah permintaan tersendiri yang sama dengan permintaan terakhir $\left(Y_{i}\right)$, apabila kedua variabel lainnya sama dengan nol. Persamaan (7) merupakan persamaan dasar sistem I-O dalam setiap persoalan umum.

\section{Analisis Angka Pengganda}

Angka pengganda output sektor $j$ menggambarkan besarnya perubahan total output dalam perekonomian akibat satu unit perubahan permintaan akhir di sektor $j$.Semakin besar angka pengganda output semakin penting peranan sektor tersebut dalam output perekonomian sehingga bisa disebut sektor unggulan. Angka pengganda output untuk sektor $j$ diformulasikan sebagai $B_{j}=\Sigma_{i} b_{i j}$

\section{E. Analisis Keterkaitan}

Indeks daya penyebaran dan derajat kepekaan merupakan lanjutan dari matrik pengganda (matric inverse). Nilai Indeks daya penyebaran 
dapat pula dikatakan sebagai nilai indeks keterkaitan ke belakang (backward lingkages) sedangkan indeks derajat kepekaan dapat pula disebut indeks keterkaitan ke depan (forward lingkages)

Analisa Indeks Backward Lingkages dan Indeks Forward Lingkages dapat memberikan gambaran mengenai kinerja dari masing-masing sektor dalam tabel input-output terhadap perekonomian wilayah. Untuk nilai indeks daya penyebaran dan derajat kepekaan yang berada $>1$, ini berarti bahwa sektor tersebut memiliki kinerja diatas rata-rata dari total seluruh perekonomian di wilayah tersebut dan begitupula sebaliknya jika berada < 1 maka kinerjanya di bawah nilai rata-rata dari total seluruh perekonomiannya.

Tabel 2. Koefisien Input

\begin{tabular}{clc}
\hline No & Sektor & Koefisien Input \\
\hline $\mathbf{1}$ & Padi & 0.385 \\
$\mathbf{2}$ & Jagung & 0.388 \\
$\mathbf{3}$ & Ubi & 0.250 \\
$\mathbf{4}$ & Hasil lelang ikan & 0.257 \\
$\mathbf{5}$ & Pengolahan ikan & 0.223 \\
$\mathbf{6}$ & Bahan melaut & 0.137 \\
$\mathbf{7}$ & Industri perkapalan & 0.395 \\
$\mathbf{8}$ & Transportasi & 0.219 \\
$\mathbf{9}$ & Pertanian lainnya & 0.340 \\
$\mathbf{1 0}$ & Jasa Lainnya & 0.367 \\
\hline
\end{tabular}

Dari tabel koefisien input terlihat bahwa pengaruh terbesar masih diduduki oleh produksi padi dan jagung, serta industry perkapalan hal ini wajar mengingat daerah Watulimo memiliki area pertanian yang cukup luas dan nelayan yang cukup banyak. Dari sektor industri pengolahan ikan, dan penjualan ikan juga mempunyai peranan meski sedikit di bawah rata-rata.

\section{HASIL DAN PEMBAHASAN}

Sesuai dengan rencana bahwa Tabel IO disusun berdasarkan sektor-sektor yang akan memberikan pengaruh pada ekonomi wilayah tersebut.

\section{a. Koefisien input}

Koefisien input (input-output coefisien) sering disebut juga sebagai matrik $A$, atau koefisien input langsung (direct input coefisien) atau matrik teknologi. Disebut sebagai matrik teknologi karena koefisien ini dapat diterjemahkan sebagai jumlah input yang digunakan untuk memproduksi satu unit output sektor $\mathrm{j}$ yang berasal dari sektor i.
Indeks daya penyebaran dan derajat kepekaan merupakan lanjutan dari matrik pengganda (matric inverse). Nilai Indeks daya penyebaran dapat pula dikatakan sebagai nilai indeks keterkaitan ke belakang (backward lingkages) sedangkan indeks derajat kepekaan dapat pula disebut indeks keterkaitan ke depan (forward lingkages)

\section{b. Indeks daya penyebaran dan derajat kepekaan}

Tabel 3. Indeks daya penyebaran dan derajat kepekaan

\begin{tabular}{llll}
\hline No & Sektor & \multicolumn{2}{c}{ Indeks } \\
\cline { 3 - 4 } & & Daya Penyebaran & Derajat Kepekaan \\
\hline $\mathbf{1}$ & Padi & 1.279 & 1.050 \\
$\mathbf{2}$ & Jagung & 0.028 & 0.979 \\
$\mathbf{3}$ & Ubi & 0.027 & 0.799 \\
$\mathbf{4}$ & Hasil lelang ikan & 0.077 & 1.028 \\
$\mathbf{5}$ & Pengolahan ikan & 0.092 & 1.124 \\
$\mathbf{6}$ & Bahan melaut & 0.446 & 0.939
\end{tabular}


Jurnal Kelautan, 10(2), 185-191 (2017)

\begin{tabular}{llll}
$\mathbf{7}$ & Industri perkapalan & 0.089 & 1.021 \\
$\mathbf{8}$ & Transportasi & 0.427 & 1.196 \\
$\mathbf{9}$ & Pertanian lainnya & 0.033 & 0.938 \\
$\mathbf{1 0}$ & Jasa Lainnya & 0.501 & 0.927 \\
\hline
\end{tabular}

Dari data terlihat yang masuk di sektor kuadran I adalah padi, sektor ini sangat berpengaruh baik ke depan maupun ke belakang.

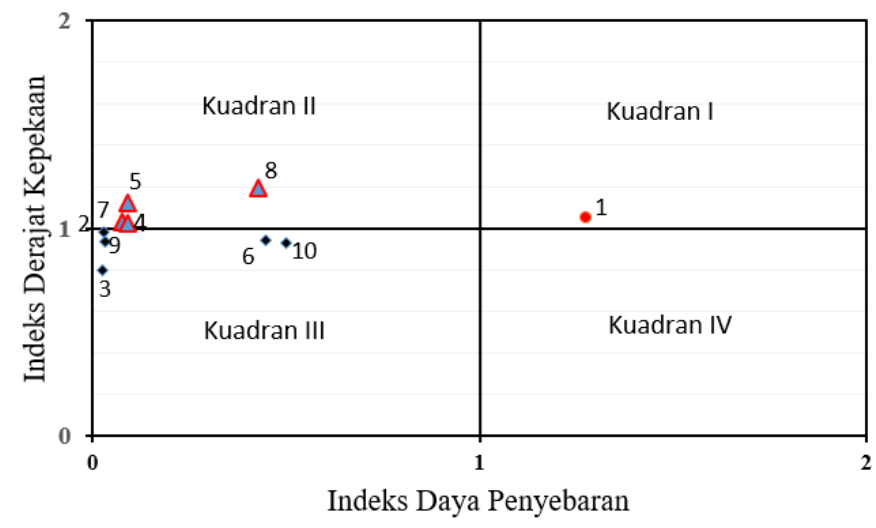

Gambar 1. Posisi kuadran masing-masing sektor

Kuadran II ditempati produk lelang ikan, pengolahan ikan, industri perkapalan dan transportasi hal ini menunjukkan bahwa sektor ini memiliki karakteristik rendahnya backward lingkages atau rendah terhadap keterkaitan kebelakang namun memiliki keterkaitan kedepan I forward lingkages yang tinggi. Selain itu rendahnya keterkaitan terhadap sektor yang menjadi input atau kurang mampunya sektor ini menyerap output yang dihasilkan dalam wilayah tersebut.

Kuadran III ditempati produk jagung, ubi, bahan melaut, pertanian lain dan jasa lainnya. Sektor yang masuk dalam kuadran ini merupakan sektor yang memiliki nilai indeks backward lingkages dan indeks forward lingkages $<1$ dimana artinya adalah sektor ini kemampuan untuk menggerakkan sektor yang menjadi input dan sektor yang memanfaatkan output sektor ini dibawah rata-rata total perekonomian sehingga sektor ini biasanya kurang diunggulkan.

\section{KESIMPULAN DAN SARAN}

Dari uraian analisa dan uraian perhitungan dengan metode Input -Output Analisis, berdasarkan data produksi ikan, dan sektor penggunaannya, peran PPN Prigi di daerah Watulimo terhadap laju perokonomian daerah tersebut dapat disimpulan bahwa:

- Derajat kepekaan produk perikanan (1.124) dan industrinya (1.021) memiliki keterkaitan cukup tinggi ke depan namun masih rendah ke belakangnya (0.092 dan 0.089 ), artinya sektor tersebut mampu menarik sektor hulu dibandingkan sektor hilirnya, sehingga perlu upaya untuk lebih peningkatannya dengan penambahan investasi.

- Pelabuhan ikan PPN Prigi mampu menjadikan kawasan tersebut memiliki keunggulan di sektor perikanan ke depan jika dibina dengan baik, terlihat dengan banyaknya sektor perikanan yang menunjang perekonomian wilayah tersebut.

\section{DAFTAR PUSTAKA}

Dault, A., Kohar, A., \& Suherman, A. (2008). Analisis Keterkaitan Sektor Perikanan Dengan Sektor Lain Pada Perekonomian Jawa Tengah. Saintek Perikanan: Indonesian Journal of Fisheries Science and Technology, 4(1), 1-8.

Dahuri, R. (2003). Paradigma Baru Pembangunan Indonesia Berbasis Kelautan. Orasi Ilmiah Guru Besar Tetap Bidang Pengelolaan Sumberdaya Pesisir dan Lautan. Fakultas Perikanan dan IImu Kelautan, Institut Pertanian Bogor, Bogor.

Badan Pusat Statistik. (2008) Kerangka Teori dan Analisis Tabel Input-Output, Jakarta.

Ermawan, R. W. (2008). Kajian Sumberdaya Pantai untuk Kesesuaian Ekowisata di Pantai Prigi, Kabupaten Trenggalek, Provinsi Jawa Timur. Skripsi. Fakultas Peikanan dan IImu Kelautan, Institut Petanian Bogor.

Soemarno, M.S. (2011), Tabel Input Output (IO),Materi Kuliah Perencanaan Lingkungan dan Pengembangan Wilayah. 
Nurhadi dan Sumarsono, Analisis Dampak Pelabuhan Ikan

BPS Kabupaten Trenggalek, Kecamatan Watulimo dalam angka 2014, Katalog BPS Tahun 2014.

http:/junaidi-dummy.blogspot.com/2009/05/bag2-tip-trik-excel.html

http://pipp.djpt.kkp.go.id/profilpelabuhan/informa si/1178/kelembagaan

http://staff.uny.ac.id/sites/default/files/tmp/MSEX CEL4DataAnalysis.pdf

http://trenggalekkab.bps.go.id/index.php?hal=pu blikasi_detil\&id=57 